\title{
Foreword: Joe R. Lansdale
}

Bill Crider

I've known Joe R. Lansdale for nearly thirty years. That's hard for me to believe, since it seems more like a few weeks, but it's true. I remember our first meeting with such clarity that I can play it back in my head like a movie.

The year was 1979. The place was a hallway in the Memorial Student Center at Texas A\&M University, just outside the dealers' room, and the occasion was AggieCon X. It was the last day of the convention, and I suppose my wife, Judy, and I had made one last round of the dealers' tables before leaving for home. As we stepped out the door of the room, I happened to glance at the name tag on a guy standing over by the windows: Joe R. Lansdale.

The name was familiar. While I'd never seen Joe before, I'd read his letters in The Mystery Fancier, a "fanzine" devoted to mystery fiction. The editor, Guy M. Townsend, published articles and book reviews written by mystery fans who wrote them for the love of the genre and who received no payment for their work. There was also a section devoted to letters from readers who had something to say about the contents, and that's where I'd seen Joe's name. As anyone who knows him can tell you, Joe always has something to say.

I walked over to Joe and his wife, Karen, and said to him, "I think I know you from another fandom."

Joe looked at me as if to say, "What on earth are you talking about, you old coot?" (I was not yet forty, Joe not yet thirty.)

I introduced myself and explained where I'd seen his name. He warmed up a bit then because he'd seen my name in the same publication. We introduced our wives and started a conversation about writers, writing, books, and movies. We discovered that we had a lot 
in common, and the conversation we began then has lasted from that day to this, although it's expanded to include many other topics. At first the conversation was conducted in large part by letters, the kind we banged out on old manual typewriters. Later it included e-mail and phone calls, and of course we've talked face to face at many a convention over the years.

I've always felt privileged to take part in this extended conversation and in my friendship with Joe. Try to imagine how exciting it would be to read Act of Love and The Nightrunners in manuscript, to see bits and pieces of "The Fat Man and the Elephant" before they coalesced into a story, or, best of all, to hear Joe tell the story that became "Mister Weed-Eater" before a word was ever set down on paper. Those were the days.

Or maybe not, because Joe wasn't yet selling steadily, much less making any money on his writing. There were times when his agent would have to send him stamps so he could mail his manuscripts, times when Joe and Karen would bring a loaf of bread and a jar of peanut butter to a convention to save money on food.

The lean times, however, did nothing at all to change Joe's mind about his talent and where it was going to take him. I've never met anyone more fiercely committed to his writing or more certain that sooner or later his name on a book or story was going to make people eager to read it. I've never forgotten how angry he became once when someone called him a "neo-pro."

Sometimes I wonder if Joe ever expected to be renowned not only in this country but in France and Italy, where he's now regarded as a literary figure on a par with Hemingway and is treated more like a rock star than a writer. But then I remind myself that he probably expects to attain that kind of recognition right here, any day now. I, for one, think he deserves it, and I believe that after reading the stories in this book, you're going to think so too.

$\mathrm{Ah}$, the stories. Hilarious, vivid, vulgar, poignant, profane, profound, colorful, and unforgettable. Not to mention unique. There's nothing else like them, because a Lansdale story is sui generis. A lot of younger writers have clearly been influenced by their reading of Lansdale's work, and their stories have traces of Lansdale DNA in them, but no one has ever duplicated the singular qualities that make a Lansdale story his own.

This collection begins with a little tale I've already mentioned, 
"Mister Weed-Eater." Joe swears that the tale is based on actual events, and long before he wrote it down, I heard him relate some of the incidents it contains to rooms full of people who were laughing so hard that I thought they might strangle themselves. Anyone who doubts that Joe is a natural-born storyteller would have all disbelief removed after hearing him launch into some supposedly true story like this one or the one about the telephone woman (which isn't included here).

"Tight Little Stitches in a Dead Man's Back" isn't funny at all. It's a post-apocalyptic science-fiction horror tale that will give you bad dreams, the kind you awaken from in a cold sweat, hoping that you don't go back to sleep for a while. On a more cheerful note, the narrator of the story refers to martial arts on the very first page. Did I mention that Joe, in addition to being a fine writer, is also superbly skilled in the martial arts? He devised a system known as Shen Chuan and has his own school where he and others teach. He's been inducted into both the International Martial Arts Hall of Fame and the Texas Martial Arts Hall of Fame, and he holds any number of black belts. In other words, you don't want to mess with him. I've seen him in action, and I know.

Speaking of the apocalypse, many of the people living in Galveston, Texas, on September 8, 1900, must have thought it had arrived. In "The Big Blow," Lansdale imagines what might have happened if Jack Jackson had been in a prize fight that night with a man paid not just to beat him but to kill him. The storm and its aftermath are terrifying in themselves, but the human story is what takes center stage here, and what a story it is, laugh-out-loud funny at one point, frightening at the next. This story alone could make a writer's reputation, but it's just one of many in the Lansdale canon.

The Magic Wagon is a western novel, true, but that's like saying that the Grand Canyon is a hole in the ground. This slim book is one of the wildest westerns ever written, and even that understates the case. I remember that when it came out in paperback, James Reasoner, a writer friend, said that he loved to think of someone going into a bookstore for a Louis L'Amour book and spotting The Magic Wagon on the shelf next to it, thanks to alphabetical order: "Well, I guess I might as well pick this'n up, too. Looks short, and it's got a covered wagon on the front." Sure enough, it does, but the contents are a long way from Louis L'Amour. It has a wrestling ape, the trick-shooting son of Wild Bill Hickok, and Wild Bill himself, or at least his petrified 
corpse. Also one of Lansdale's classic nose-picking scenes, maybe his best. You have to wonder what that fellow must have thought when he read it. I'd like to have seen his face.

The Great Depression was the time of Bonnie and Clyde, and of other bank robbers, like the ones in "Dirt Devils," a story with sudden, sharp violence with a sense of doom hanging over everything like the dust cloud that the wind twists into a dust devil in the story's opening scene.

In "The Pit," a man named Harry takes a wrong turn. A really wrong turn. He winds up fighting for his life in the pit, after the warm-up dogfight, with an audience screaming for blood. Throw in a crazed preacher and a rattlesnake named Sapphire, and you have a combination of such grisly humor and bloodletting that you might want to turn away. But you won't be able to, and after you think about what you've read for a while, you might just discover that it's also a scathing commentary on the issue of race in this country.

"Night They Missed the Horror Show" is one that Lansdale himself labels "a story that doesn't flinch." I couldn't have put it better myself, and this might be my favorite of all his stories. I like the black humor and the horrible inevitability of the plot as it uncoils like a rattler, with a bite that's just as vicious as any snake's.

"Bubba Ho-Tep" attained fame far beyond its print origins when it was filmed by Don Coscarelli. It became known as the funniest, most satisfyingly entertaining movie in a generation. Or maybe two. But don't let the fact that it was a great movie experience deter you from reading the story. When Elvis and JFK battle the mummy in the nursing home, it's more stirring than anything on the screen. Funnier, too, and more touching.

It's impossible for me to describe "The Fat Man and the Elephant." I can tell you it's about a failed preacher named Sonny Guy, who thinks he's found his totem animal in a sad and sickly sideshow elephant, but that doesn't come anywhere near to getting at the heart of the matter. Just read it.

Lansdale's fascination with drive-in theaters has shown up often in his fiction, but he's never put it to use more effectively than in $A$ Fine Dark Line, a novel set in the not-too-distant American past that captures a lot of the good and the bad about that time and brings it all home in a fine coming-of-age novel. There's only a taste of it here, and it will leave you wanting more. 
When Lansdale was asked to write a story for an anthology about horse racing, he naturally couldn't quite follow the guidelines. Readers can be happy he didn't, because what he came up with was "White Mule, Spotted Pig," which marginally involves a mule race but is a lot more about freedom and friendship and responsibility than about racing. It brings the collection to a fitting close.

And there you have it. High art and low comedy; sex and violence; humor and sadness; love and death; all in one package. Not a neat package, never that, because it holds living, breathing people who lead often messy lives, people whose stories will keep you riveted while you read and who will stay with you long after you've closed the book, even if you try to forget them. I've taken up enough of your time here. Go read the stories. You'll be glad you did. 
THIS PAGE INTENTIONALLY LEFT BLANK 
Sanctified and Chicken-Fried 
THIS PAGE INTENTIONALLY LEFT BLANK 